IZA DP No. 6152

Disability and Job Mismatches in the Australian Labour Market

Melanie Jones

Kostas Mavromaras

Peter Sloane

Zhang Wei

November 2011 


\title{
Disability and Job Mismatches in the Australian Labour Market
}

\author{
Melanie Jones \\ WELMERC, Swansea University
}

Kostas Mavromaras

NILS, Flinders University

and IZA

Peter Sloane

NILS, Flinders University,

WELMERC and IZA

Zhang Wei

NILS, Flinders University

\section{Discussion Paper No. 6152 \\ November 2011}

\author{
IZA \\ P.O. Box 7240 \\ 53072 Bonn \\ Germany \\ Phone: +49-228-3894-0 \\ Fax: +49-228-3894-180 \\ E-mail: iza@iza.org
}

\begin{abstract}
Any opinions expressed here are those of the author(s) and not those of IZA. Research published in this series may include views on policy, but the institute itself takes no institutional policy positions.

The Institute for the Study of Labor (IZA) in Bonn is a local and virtual international research center and a place of communication between science, politics and business. IZA is an independent nonprofit organization supported by Deutsche Post Foundation. The center is associated with the University of Bonn and offers a stimulating research environment through its international network, workshops and conferences, data service, project support, research visits and doctoral program. IZA engages in (i) original and internationally competitive research in all fields of labor economics, (ii) development of policy concepts, and (iii) dissemination of research results and concepts to the interested public.
\end{abstract}

IZA Discussion Papers often represent preliminary work and are circulated to encourage discussion. Citation of such a paper should account for its provisional character. A revised version may be available directly from the author. 


\begin{abstract}
Disability and Job Mismatches in the Australian Labour Market ${ }^{*}$

We examine the relationship between disability, job mismatch, earnings and job satisfaction, using panel estimation on data from the Household, Income and Labour Dynamics in Australia (HILDA) Survey (2001-2008). While we do not find any relationship between worklimiting disability and over-skilling, it appears that there is a positive relationship between work-limiting disability and over-education, which is consistent with disability onset leading to downward occupational movement, at least in relative terms. We find a negative correlation between work-limiting disability and both earnings and job satisfaction. However, there is only evidence of a causal relationship in terms of the latter, where the impact of disability is found to be multifaceted.
\end{abstract}

JEL Classification: $\quad 10, \mathrm{~J} 2, \mathrm{~J} 3, \mathrm{~J} 7, \mathrm{~J} 24, \mathrm{~J} 31$

Keywords: job mismatch, disability, earnings, job satisfaction

Corresponding author:

Kostas Mavromaras

National Institute of Labour Studies

Flinders University

GPO Box 2100

Adelaide, South Australia 5001

Australia

E-mail: k.mavromaras@flinders.edu.au

\footnotetext{
* The data used is the confidentialised unit record file from the Household, Income and Labour Dynamics in Australia (HILDA) survey. The HILDA Survey Project was initiated, and is funded, by the Australian Government Department of Families, Housing, Community Services and Indigenous Affairs, and is managed by the Melbourne Institute of Applied Economic and Social Research. Financial support by Faculty of Social and Behavioural Science and the National Institute of Labour Studies, Flinders University is gratefully acknowledged. We are also grateful for helpful comments from participants of the Scottish Economics Society 2011 Annual Conference.
} 


\section{Introduction and Background}

The influence of disability on labour market outcomes is an important aspect of the Australian labour market. Improving labour market outcomes for people with a disability is a part of the Australian Government's social inclusion agenda (see, Commonwealth of Australia 2008). In 2003, about 17 per cent of the Australian working age population reported a disability, comprising some 1.15 million men and 1.10 million women. ${ }^{1}$ There is a growing body of evidence demonstrating the disadvantaged position of disabled people in the labour market. For instance, Wilkins (2004) and Mavromaras et al. (2006) show that people with disabilities have a much lower labour market participation rate than their non-disabled counterparts in Australia. Individuals who report a disability also have significantly lower average educational attainment and, when in work, lower earnings. DeLeire (2001) distinguishes between work-limiting and non-work-limiting disability to separate the effects of discrimination from functional limitations on the disability earnings gap and finds the latter effect is more significant in the USA. This argument is supported by Jones et al. (2006) who suggest that the unobserved productivity effect of disability explains most of the earning gaps in the UK.

At the same time, there is a growing literature focusing on labour market mismatch. Job mismatch has also become an issue of particular policy concern, because it is seen as damaging to competitiveness in both Europe and Australia (see, for example, European Commission, 2009). The earlier mismatch literature is based on cross-section analysis and finds that over-education leads to pay penalties (see, for example, Sloane et al., 1999) and reductions in job satisfaction consistent with it being an involuntary state (see Battu et al., 1999; Chevalier, 2003; Fleming and Kler, 2008). Similar effects occur in the case of over-

\footnotetext{
${ }^{1}$ The Australian Bureau of Statistics (ABS) 2003 Survey of Disability, Ageing and Carers.
} 
skilling (Allen and Van der Velden, 2001; Kler, 2005; Green and McIntosh, 2007; McGuinness and Wooden, 2009; Mavromaras et al., 2010a). Mavromaras et al. (2010b) further suggest that skill and educational mismatches are distinct phenomena with different labour market outcomes and that it is their combination which results in the most severe labour market outcomes.

However, the relationship between disability and job mismatches has been relatively neglected in the literature. There are two recent exceptions to this. One is Blazquez and Malo (2005) who find disability does not have a significant impact on educational mismatch in Spain. The other is Jones and Sloane (2010) who find that disabled workers are more likely to be skill mismatched in the UK, but their analysis is limited because it is only based on crosssection evidence. The current paper extends this analysis by investigating the impact of disability on job mismatches, wages and job satisfaction in Australia using panel data. The use of panel estimation brings major benefits to the way we can analyse the data at hand, especially where it enables us to control for certain forms of unobserved heterogeneity and inform our understanding of causal relationships. The use of panel evidence highlights new aspects of the relationship between disabilities and long-term health conditions, as it allows us to follow specific individuals and investigate the complex picture of disabilities in terms of their onset, continuation and, as the data show, recovery as well. We are able to distinguish between disabilities which are work-limiting and non-work-limiting in nature, a distinction which, as noted above, has proved particularly important in previous work. We are also able to consider multiple forms of mismatch, or more specifically distinguish between educational and skill mismatch which has been identified as critical in recent analysis (Mavromaras et al., 2010b). 
In addition to examining the incidence of mismatch, we assess the impact of mismatch on wages and job satisfaction between disabled and non-disabled workers and consider whether this is a mechanism through which differences in outcomes between the disability groups may be generated. Indeed, the influence of disability on productivity may itself be thought of as a form of matching, subject to constraints such as those between functional limitations and job demands. Thus, we may expect disabled workers to be particularly sensitive to the educational and skill mismatch examined here. While investigating the causes of the disability earnings gap has been central to the international literature the issue of job satisfaction has not been a prominent feature (see, Uppal, 2005 for an exception). We argue that by considering job satisfaction in the analysis we provide a more comprehensive picture of the impact of disability than focusing on earnings alone. Our core research questions are thus the following:

- What is the effect of disability on mismatch?

- What is the effect of disability on wages and is it influenced by mismatch?

- What is the effect of disability on job satisfaction and is it influenced by mismatch?

This paper is not only the first to consider the relationship between disability and job mismatch in Australia, but in utilising panel data from the Household, Income and Labour Dynamics in Australia (HILDA) survey it is the first to address a number of unsolved empirical issues in the international literature. In particular, we use panel estimation techniques which control for time invariant unobserved individual heterogeneity and allow us to come closer to making inferences about the causal effects of disability on mismatch, earnings and job satisfaction. There are limitations in using self-reported information on over-skilling, disability and job satisfaction, since the reporting of such information may be 
subject to common influences such as personality and other constant but unobserved personal traits, which implies that the use in this paper of panel estimation that controls for time invariant unobserved individual heterogeneity is an important methodological advance. The use of panel estimation may also confer additional advantages to this paper by helping correct for potential sample selection bias. Sample selection bias can always be a problem in the context of labour market status choices, and it is worth noting in this context, that Dustmann and Rochina-Barrachina (2007) show that if the selection process is time constant, panel estimators also solve the problem of potential sample selection bias. As such, this paper also contributes to the emerging panel data analysis of disability where recent contributions have focused on labour market participation (Oguzoglu, 2010, 2011) and hours of work (Cai et al., 2008).

\section{The Household, Income and Labour Dynamics in Australia (HILDA)}

\section{Survey}

This paper uses the first eight waves of the HILDA survey. Modelled on household panel surveys undertaken in other countries, the HILDA survey began in 2001 with a large national probability sample of Australian households and their members. ${ }^{2}$ The sample used in this paper is restricted to an unbalanced panel of all working-age employees who provide complete information on the variables of interest. The sample retained by the paper for the econometric analysis that follows is approximately 8,000 observations per wave, which is just under half the total number of all HILDA respondents.

\footnotetext{
${ }^{2}$ See Watson and Wooden (2004) for a detailed description of the HILDA data.
} 


\subsection{Disability}

In the HILDA survey, employees were asked: Do you have any long-term health condition, impairment or disability that restricts you in your everyday activities, and has lasted or is likely to last, for 6 months or more? Those who answer “yes” were further asked: Does your condition limit the type of work or the amount of work you can do? We define a person to have a disability which is work-limiting if he or she answers "yes" to both questions. Those who answer "yes" to the first question and "no" to the second are defined as having a nonwork-limiting disability. The remainder of the sample, who do not have a disability, are referred to as non-disabled. ${ }^{3}$ Under this definition, 14.1 per cent of employees are classified as disabled, among whom 6.7 per cent are non-work-limited and 7.4 per cent are worklimited, as shown in Table 1.

Table 1: Disability status of working age population in Australia

\begin{tabular}{|c|c|c|c|c|c|c|c|c|}
\hline & \multicolumn{2}{|c|}{$\begin{array}{l}\text { Employed } \\
\text { Males }\end{array}$} & \multicolumn{2}{|c|}{$\begin{array}{l}\text { Employed } \\
\text { Females }\end{array}$} & \multicolumn{2}{|c|}{$\begin{array}{l}\text { Employed } \\
\text { Total }\end{array}$} & \multicolumn{2}{|c|}{$\begin{array}{l}\text { Population } \\
\text { Total }\end{array}$} \\
\hline & Persons & $\%$ & Persons & $\%$ & Persons & $\%$ & Persons & $\%$ \\
\hline $\begin{array}{l}\text { No disability } \\
\text { Non-work- }\end{array}$ & 22,567 & 85.5 & 22,230 & 86.2 & 44,797 & 85.8 & 65,607 & 79.8 \\
\hline $\begin{array}{l}\text { limiting disability } \\
\text { Work-limiting }\end{array}$ & 1,980 & 7.5 & 1,539 & 6.0 & 3,519 & 6.7 & 5,386 & 6.6 \\
\hline disability & 1,850 & 7.0 & 2,031 & 7.9 & 3,881 & 7.4 & 11,185 & 13.6 \\
\hline Total & 26,397 & 100.0 & 25,800 & 100.0 & 52,197 & 100.0 & 82,178 & 100.0 \\
\hline
\end{tabular}

Notes: HILDA waves 2001-2008. Unit of observation is person-years.

It is important to note that the percentage of employees with a work-limiting disability is considerably lower than that of the whole working age population (7.4 percent against 13.6 percent in Table 1), which is consistent with the lower rate of labour force participation among people with work-limited disabilities. Consistent with the international literature (see,

\footnotetext{
${ }^{3}$ Self-reported information of this type has been extensively used in the international literature. However, it is not without some limitations. In particular, it has been argued that this type of information is subject to 'justification bias', or in other words there may be a greater incentive for those who do not participate in the labour force to report disability. This bias is reduced, but we acknowledge that it may not be eliminated, by focusing on employees.
} 
for example, Jones and Sloane, 2010) employees who report a disability are more likely to not have completed school and are less likely to have completed higher education (see Table 2).

Table 2: Highest educational attainment by disability status

\begin{tabular}{lrcccccc}
\hline & & $\begin{array}{c}\text { Did not } \\
\text { complete } \\
\text { school }\end{array}$ & $\begin{array}{c}\text { Only } \\
\text { complete } \\
\text { school }\end{array}$ & $\begin{array}{c}\text { Certificate } \\
\text { III/IV }\end{array}$ & Diplomas & $\begin{array}{c}\text { University } \\
\text { graduates }\end{array}$ & Total \\
\hline No disability & Persons & 10,887 & 9,009 & 8,885 & 4,064 & 11,929 & 44,774 \\
& $\%$ & 24.3 & 20.1 & 19.8 & 9.1 & 26.6 & 100.0 \\
Work-limiting & Persons & 1,216 & 566 & 881 & 310 & 905 & 3,878 \\
disability & $\%$ & 31.4 & 14.6 & 22.7 & 8.0 & 23.3 & 100.0 \\
Non-work- & Persons & 992 & 555 & 854 & 326 & 787 & 3,514 \\
limiting disability & $\%$ & 28.2 & 15.8 & 24.3 & 9.3 & 22.4 & 100.0 \\
Total & Persons & 13,095 & 10,130 & 10,620 & 4,700 & 13,621 & 52,166 \\
& $\%$ & 25.1 & 19.4 & 20.4 & 9.0 & 26.1 & 100.0 \\
\hline
\end{tabular}

Notes: HILDA waves 2001-2008. Unit of observation is person-years. Self employed are excluded.

\subsection{Job Mismatch}

We define over-skilling as the situation where an employee is not utilising their skills and abilities fully in their work. The information is derived from the HILDA survey by using the response scored on a seven-point scale to the statement I use many of my skills and abilities in my current job. Responses range from strongly disagree (1) to strongly agree (7). Following extensive sensitivity analyses, individuals selecting $1,2,3$ or 4 on the scale were classified as over-skilled, whereas those selecting 5 or higher were classified as skillmatched, often referred to as well-matched. Unlike in the UK Workplace Employment Relations Survey (WERS) data there is no way of identifying under-skilling within HILDA. The distribution of mismatch by disability status is presented in Table 3. In contrast to Jones and Sloane (2010), who use a different measure of mismatch using WERS, we find no clear association between disability status and skill mismatch in Australia. Roughly a quarter of all employees report being over-skilled. 
Table 3: Skill mismatch by disability status

\begin{tabular}{lccccccccc}
\hline & $\begin{array}{c}\text { Well } \\
\text { matched }\end{array}$ & $\begin{array}{c}\text { Male } \\
\text { Over- } \\
\text { skilled }\end{array}$ & $\begin{array}{c}\text { \% Over- } \\
\text { skilled }\end{array}$ & $\begin{array}{c}\text { Well } \\
\text { matched }\end{array}$ & $\begin{array}{c}\text { Female } \\
\text { Over- } \\
\text { skilled }\end{array}$ & $\begin{array}{c}\text { \% Over- } \\
\text { skilled }\end{array}$ & $\begin{array}{c}\text { Well } \\
\text { matched }\end{array}$ & $\begin{array}{c}\text { Total } \\
\text { Over- } \\
\text { skilled }\end{array}$ & $\begin{array}{c}\text { \% Over- } \\
\text { skilled }\end{array}$ \\
\hline $\begin{array}{l}\text { No disability } \\
\begin{array}{l}\text { Work-limiting } \\
\text { disability }\end{array}\end{array}$ & 15,153 & 4,518 & 23.0 & 14,918 & 5,121 & 25.6 & 30,071 & 9,639 & 24.3 \\
$\begin{array}{l}\text { Non-work- } \\
\text { limiting disability }\end{array}$ & 1,180 & 414 & 26.0 & 1,362 & 441 & 24.5 & 2,542 & 855 & 25.2 \\
Total & 1,331 & 439 & 24.8 & 1,077 & 323 & 23.1 & 2,408 & 762 & 24.0 \\
\hline
\end{tabular}

Note: HILDA waves 2001-2008. Unit of observation is person-years. The self-employed have been excluded.

Unlike in the case of over-skilling, the HILDA survey does not contain a direct question on over-education. To overcome this we generate a measure of over-education using the 'empirical method', where an individual is classed as over-educated if they are more qualified than the norm for employees within the same occupation (see Sloane, 2003). Here we choose the mode to represent the norm for the occupation, since it is least affected by the shape of the distribution of education. We categorise employees by their years of education and their 2-digit occupational classification. A person is defined as over-educated if his or her education level is above the mode for their occupation and the rest of the sample is treated as well matched. We present the incidence of over-education by disability status in Table 4. In a similar manner to over-skilling there is no clear association between disability and overeducation, with approximately one in five workers in the sample being classified as overeducated. It should be noted that the correlation between over-skilling and over-education is low at around 0.1. 
Table 4: Over-education by disability status

\begin{tabular}{|c|c|c|c|c|c|c|c|c|c|}
\hline & \multicolumn{3}{|c|}{ Male } & \multicolumn{3}{|c|}{ Female } & \multicolumn{3}{|c|}{ Total } \\
\hline & $\begin{array}{c}\text { Well } \\
\text { matched }\end{array}$ & $\begin{array}{c}\overline{\text { Over- }} \\
\text { educated }\end{array}$ & $\begin{array}{l}\text { \% Over- } \\
\text { educated }\end{array}$ & $\begin{array}{c}\text { Well } \\
\text { matched }\end{array}$ & $\begin{array}{c}\begin{array}{l}\text { Over- } \\
\text { educated }\end{array} \\
\text { e }\end{array}$ & $\begin{array}{l}\text { \% Over- } \\
\text { educated }\end{array}$ & $\begin{array}{c}\text { Well } \\
\text { matched }\end{array}$ & $\begin{array}{c}\overline{\text { Over- }} \\
\text { educated }\end{array}$ & $\begin{array}{l}\text { \% Over- } \\
\text { educated }\end{array}$ \\
\hline $\begin{array}{l}\text { No } \\
\text { disability } \\
\text { Work- }\end{array}$ & 17,996 & 4,550 & 20.2 & 17,507 & 4,721 & 21.2 & 35,503 & 9,271 & 20.7 \\
\hline $\begin{array}{l}\text { limiting } \\
\text { disability } \\
\text { Non work- }\end{array}$ & 1,444 & 403 & 21.8 & 1,586 & 445 & 21.9 & 3,030 & 848 & 21.9 \\
\hline $\begin{array}{l}\text { limiting } \\
\text { disability }\end{array}$ & 1,590 & 385 & 19.5 & 1,238 & 301 & 19.6 & 2,828 & 686 & 19.5 \\
\hline Total & 21,030 & 5,338 & 20.2 & 20,331 & 5,467 & 21.2 & 41,361 & 10,805 & 20.7 \\
\hline
\end{tabular}

\subsection{Earnings}

Table 5 presents mean nominal hourly earnings in Australian dollars and weekly working hours by disability status. Consistent with previous evidence (see, for example, Jones et al., 2006) employees with a work-limiting disability have a lower average hourly wage and report fewer working hours. For males the raw earnings gap between disabled and nondisabled is about 10 per cent which is comparable to international estimates. The corresponding gap for women is much smaller.

Table 5: Hourly wages and weekly hours by disability status

\begin{tabular}{lcccc} 
& \multicolumn{2}{c}{ Hourly Wages } & \multicolumn{2}{c}{ Weekly Hours } \\
& Males & Females & Males & Females \\
\hline No disability & 23.5 & 20.5 & 41.2 & 30.9 \\
Non-work-limiting disability & 23.4 & 19.9 & 41.3 & 31.2 \\
Work-limiting disability & 21.2 & 20.1 & 36.9 & 28.9
\end{tabular}

Notes: HILDA waves 2001-2008. Wages are measured in Australian dollars.

\subsection{Job Satisfaction}

The HILDA survey asks employees how satisfied or dissatisfied they are with different aspects of their main job. Responses are recorded on a scale between 0 (least satisfied) and 10 (most satisfied). This includes questions on overall satisfaction along with five facets of job 
satisfaction (total pay, job security, the nature of work itself, hours of work, and flexibility). The mean for each measure of job satisfaction is reported in Table 6 by disability status. Following extensive sensitivity analyses we create a binary variable for each job satisfaction measure for use in the following regressions, indicating low satisfaction with zero for scores between 0 and 6 and high satisfaction with one for scores between 7 and 10 .

Table 6: Job satisfaction by disability status

\begin{tabular}{lcccccc} 
& \multicolumn{2}{c}{ No disability } & \multicolumn{2}{c}{$\begin{array}{c}\text { Non-work-limiting } \\
\text { disability }\end{array}$} & \multicolumn{2}{c}{$\begin{array}{c}\text { Work-limiting } \\
\text { disability }\end{array}$} \\
& Males & Females & Males & Females & Males & Females \\
\hline Overall job satisfaction & 7.5 & 7.7 & 7.5 & 7.6 & 7.2 & 7.4 \\
Satisfaction with total pay & 7.0 & 6.9 & 6.9 & 6.8 & 6.5 & 6.6 \\
Satisfaction with job security & 8.0 & 8.1 & 7.8 & 8.0 & 7.4 & 7.6 \\
Satisfaction with the nature of work & 7.6 & 7.6 & 7.5 & 7.6 & 7.3 & 7.4 \\
Satisfaction with hours of work & 7.1 & 7.3 & 7.1 & 7.1 & 6.9 & 7.0 \\
Satisfaction with flexibility & 7.3 & 7.5 & 7.2 & 7.5 & 7.2 & 7.2 \\
\hline
\end{tabular}

Notes: HILDA waves 2001-2008. Unit of observation is person-years. The self-employed have been excluded.

The results in Table 6 suggest that, in general, differences in job satisfaction between those without a disability and those with a non-work-limiting disability are relatively small both in relation to overall job satisfaction as well as individual facets of job satisfaction. It is worth noting, however, that in every case those with work-limiting disabilities have lower job satisfaction than those without a disability.

\subsection{Disability Transitions}

Table 7 shows how disability status changes over time, in the form of a table which records the percentage of transitions between data waves. Of those with no disability in the previous wave ( $t$-1) 92.3 per cent continue to report no disability in the next wave ( $t$ ), but 4.5 per cent report a non-work-limiting disability and 3.2 per cent a work-limiting disability. Table 7 
shows that there is sufficient movement between disability statuses (in the form of disability onset and recovery) to undertake panel analysis, as the application of panel analysis relies on the presence of a sufficient number of changes in status for each individual in the data at hand. Of those who reported a non-work-limiting disability in the previous wave, 56.8 per cent recovered, 29.3 per cent remained in the same state, and 13.9 per cent reported a worklimiting disability. Of those who reported a work-limiting disability in the previous wave, 33.2 per cent recovered, 13.2 percent reported a non-work-limiting disability, and 53.6 per cent remained in the same disability state.

Table 7: Transition between disability status

\begin{tabular}{|c|c|c|c|c|c|c|c|c|}
\hline & \multicolumn{8}{|c|}{ Disability status at $t$} \\
\hline & \multicolumn{2}{|c|}{ No disability } & \multicolumn{2}{|c|}{$\begin{array}{c}\text { Non-work- } \\
\text { limiting disability }\end{array}$} & \multicolumn{2}{|c|}{$\begin{array}{l}\text { Work-limiting } \\
\text { disability }\end{array}$} & \multicolumn{2}{|c|}{ Total } \\
\hline & Persons & $\%$ & Persons & $\%$ & Persons & $\%$ & Persons & $\%$ \\
\hline \multicolumn{9}{|l|}{$\begin{array}{l}\text { Disability status } \\
\text { at } t-1\end{array}$} \\
\hline $\begin{array}{l}\text { No disability } \\
\text { Non-work- }\end{array}$ & 31,594 & 92.3 & 1,541 & 4.5 & 1,078 & 3.2 & 34,213 & 100 \\
\hline $\begin{array}{l}\text { limiting disability } \\
\text { Work-limiting }\end{array}$ & 1,529 & 56.8 & 790 & 29.3 & 373 & 13.9 & 2,692 & 100 \\
\hline disability & 934 & 33.2 & 371 & 13.2 & 1,505 & 53.6 & 2,810 & 100 \\
\hline Total & 34,057 & 85.8 & 2,702 & 6.8 & 2,956 & 7.4 & 39,715 & 100 \\
\hline
\end{tabular}

Notes: HILDA waves 2002-2008.

Table 8 shows changes in self-reported skills utilisation (scores 1 to 7 ) used above to define the over-skilling variable. Those who reported no disability in the previous wave but go on to report a non-work-limiting disability in the next wave, also reported that their skill utilisation declined, whereas those who went on to report a work-limiting disability in the next wave, also reported that their skill utilisation improved. Those who report a change from a nonwork-limiting disability to a work-limiting disability, report higher scores on average, while those who report a change from a work-limiting disability to a recovery, report lower scores on average. 
Table 8: Change in skill utilisation scores by transition between disability status

\begin{tabular}{lccc}
\hline & \multicolumn{3}{c}{ Disability status at $t$} \\
\hline No disability & $\begin{array}{c}\text { Non-work- } \\
\text { limiting } \\
\text { disability }\end{array}$ & $\begin{array}{c}\text { Work-limiting } \\
\text { disability }\end{array}$ \\
\hline Disability status at $t-1$ & +0.014 & -0.022 & +0.038 \\
No disability & +0.128 & -0.017 & +0.033 \\
Non-work-limiting disability & -0.047 & +0.059 & +0.017 \\
Work-limiting disability & & & \\
\hline
\end{tabular}

Table 9 examines if the onset of disability is associated with occupational mobility. The findings support the view that disability onset may lead to relative occupational downgrading, as those who move from no disability to reporting a work-limiting disability hardly change their occupational level, while the other two groups benefit from some occupational upgrading. Similarly, individuals who recover from a non-work-limiting or work-limiting disability experience greater upward occupational mobility than those who do not. The combination of results in Table 8 and 9 suggests that, despite the downward occupational mobility, disability onset is positively associated with perceived skill utilisation which may reflect a fall in perceived skill capacity as a consequence of disability onset.

Table 9: Change in mode education level of occupation by transition between disability status

\begin{tabular}{lccc}
\hline & \multicolumn{3}{c}{ Disability status at t } \\
\hline & & $\begin{array}{c}\text { Non-work- } \\
\text { limiting } \\
\text { disability }\end{array}$ & $\begin{array}{c}\text { Work- } \\
\text { limiting } \\
\text { disability }\end{array}$ \\
\hline Disability status at $t-1$ & & & \\
No disability & +0.080 & +0.082 & +0.006 \\
Non-work-limiting disability & +0.077 & -0.019 & -0.084 \\
Work-limiting disability & +0.079 & +0.182 & +0.033 \\
\hline
\end{tabular}

Notes: HILDA waves 2002-2008. 


\section{Modelling Methodology}

\subsection{Modelling mismatch}

In the first stage of our analysis we use multivariate regression analysis to examine the determinants of skill and education mismatch separately. We model mismatch $\left(M_{i t}\right)$ in terms of over-skilling and over-education for individual $i$ in time period $t$, as a function of disability $\left(D_{i t}\right)$ which is represented by two binary variables, one for work-limiting and one for nonwork-limiting disability respectively, as follows:

$M_{i t}=\alpha_{0}+\alpha D_{i t}+\beta X_{i t}+\epsilon_{i t}$

We control for a comprehensive set of explanatory variables $\left(X_{i t}\right)$ relating to personal and workplace characteristics. These include controls for gender, age, educational attainment, marital status, presence of children, socioeconomic background, unemployment history, country of origin, employment and occupational tenure, union membership, firm size and industry. Full definitions and descriptive statistics are given in Appendix Table A1. Initially we pool data across time and estimate equation (1) using a probit model. This serves two purposes. First, it provides a set of estimates that is comparable with the majority of the (cross section) literature estimates, where panel data methods have not been utilised. Second, it provides a reasonable estimate of the overall association between disability and job mismatches. We then go on and utilise the panel nature of the data and estimate a random effects (RE) probit to control for time-invariant unobserved individual heterogeneity. We augment the RE estimation with the use of Mundlak (1978) corrections through the use of time averages of all covariates, included as additional explanatory variables, as shown in equation (2): 
$M_{i t}=\alpha_{0}+\alpha D_{i t}+\beta X_{i t}+\xi_{1} \bar{D}_{i}+\xi_{2} \bar{X}_{i}+v_{i t}$

where $\bar{D}_{i}$ and $\bar{X}_{i}$ are the time averages of $D_{i t}$ and $X_{i t}$ for individual $i$ respectively, and $v_{i t}$ is a composite error term. The inclusion of the Mundlak corrections resolves the issue of potential correlation between the individual effect and the explanatory variables by assuming a relationship between the individual effect and the means of the time-varying variables for each individual. Thus the advantage of using the RE estimator with the Mundlak corrections is that this method produces estimates that are very close to those obtained using the Fixed Effects estimator (in terms of an unbiased estimate of the within variation in the data) combined with an estimate for each individual time-constant variable (which represents the between variation in the data, and which is usually all summed up in the individual fixed effect estimate).

\subsection{Modelling the effects of disability and mismatch on earnings and job satisfaction}

To investigate the effects of disability and job mismatch on earnings we similarly estimate an earnings function with the following two different specifications:

$\ln W_{i t}=\alpha_{0}+\alpha D_{i t}+\beta X_{i t}+\epsilon_{i t}$

$\ln W_{i t}=\alpha_{0}+\alpha D_{i t}+\varphi M_{i t}+\beta X_{i t}+\epsilon_{i t}$

where $\ln W_{i t}$ is the log of the weekly wage. The remaining variables are the same as those in Equation 1 above. Equation 3 excludes whilst Equation 4 includes the mismatch variables. As above, we initially estimate these models using pooled OLS but then consider the panel 
nature of the data and estimate the earnings equation using random effects with a Mundlak (1978) correction. Equation 4 constrains the influence of mismatch to be common across disability groups and we introduce interactions between disability and job mismatch to allow the influence of mismatch to vary by disability status in Equation 5 below:

$\ln W_{i t}=\alpha_{0}+\alpha D_{i t}+\varphi M_{i t}+\beta X_{i t}+\gamma D_{i t} * M_{i t}+\epsilon_{i t}$

We use similar model specifications to estimate the effect of mismatch and disability on overall job satisfaction and the separate facets of job satisfaction, although, since the dependent variables are measured using binary indicators (see Section 2.4), we use a Random Effects Probit estimation method.

\section{Estimation Results}

\subsection{Disability and mismatch}

Table 10 below presents the coefficients from the pooled probit models and the random effects (RE) model with Mundlak correction. The influence of disability on over-skilling and over-education is presented in the upper and lower panels of the table respectively. In the pooled models there is no evidence of an influence of disability (whether or not it is worklimiting in nature) on over-skilling. However, after controlling for unobservable characteristics through the panel estimation, work-limiting disability is positively associated with over-education. This effect remains significant, and is actually strengthened, in the Mundlak specification. It is worth noting that the Mundlak specification is the most likely specification to have controlled for both potential unobservable and selection biases. The estimated relationship between disability and overeducation is consistent with a causal 
interpretation. That is, becoming work-limiting disabled increases the probability of becoming overeducated, and it shows the added information about disability and mismatch that can be derived through panel estimation.

Table 10: The impact of disability on job mismatch

\begin{tabular}{|c|c|c|}
\hline & \multicolumn{2}{|c|}{ Relative to non-disabled } \\
\hline & Non-work-limiting disabled & Work-limiting disabled \\
\hline \multicolumn{3}{|l|}{ Impact on over-skilling } \\
\hline Pooled probit & $\begin{array}{l}0.022 \\
(0.83)\end{array}$ & $\begin{array}{l}-0.014 \\
(-0.54)\end{array}$ \\
\hline RE with Mundlak corrections & $\begin{array}{r}0.079 * \\
(1.83)\end{array}$ & $\begin{array}{l}-0.049 \\
(-0.99)\end{array}$ \\
\hline $\begin{array}{l}\text { Mismatch incidence } \\
\text { Sample size }\end{array}$ & 3170 & 3397 \\
\hline \multicolumn{3}{|l|}{ Impact on over-education } \\
\hline Pooled probit & $\begin{array}{r}-0.013 \\
(0.47)\end{array}$ & $\begin{array}{l}0.050^{*} \\
(1.78)\end{array}$ \\
\hline RE with Mundlak corrections & $\begin{array}{l}0.045 \\
(0.79)\end{array}$ & $\begin{array}{l}0.118^{*} \\
(1.81)\end{array}$ \\
\hline $\begin{array}{l}\text { Mismatch incidence } \\
\text { Sample size }\end{array}$ & 3514 & 47063 \\
\hline
\end{tabular}

The estimated effect of disability on mismatch may arise as a consequence of disability onset being associated with a downward occupational movement such that qualifications become less well utilised in post-disability employment as described earlier. In the Mundlak specification becoming non-work-limiting disabled (and surprisingly not work-limiting disabled) increases the probability of reporting over-skilling. Thus, it appears that the nonwork-limiting disabled report that they are not given jobs commensurate with their skills and abilities, whereas the work-limiting disabled recognise the possible limitations introduced by their disability. 


\subsection{Disability, wages and job satisfaction}

In the upper and lower panels of Table 11 we consider the implications of disability and mismatch on earnings and job satisfaction respectively. Again we present estimates from both pooled and RE panel models and, for each, we present two specifications, the first with whilst the second without the mismatch variables. Consistent with the existing international literature, the pooled models indicate that disability has a negative association with both wages and job satisfaction and, in both cases the effects are stronger for the work-limiting disabled than for the non-work-limiting disabled.

Table 11: The impact of disability on weekly earnings and job satisfaction

\begin{tabular}{|c|c|c|c|c|}
\hline & \multicolumn{4}{|c|}{ Relative to non-disabled and well-matched } \\
\hline & $\begin{array}{c}\text { Non-work- } \\
\text { limiting } \\
\text { disabled }\end{array}$ & $\begin{array}{c}\text { Work-limiting } \\
\text { disabled }\end{array}$ & Over-skilled & $\begin{array}{c}\text { Over- } \\
\text { educated }\end{array}$ \\
\hline \multicolumn{5}{|l|}{ Impact on weekly wage } \\
\hline Pooled OLS & $\begin{array}{c}-0.022 * * * \\
(-2.69)\end{array}$ & $\begin{array}{c}-0.090 * * * \\
(-11.04)\end{array}$ & - & - \\
\hline Pooled OLS & $\begin{array}{c}-0.017 * * \\
(-2.01)\end{array}$ & $\begin{array}{c}-0.079 * * * \\
(-9.45)\end{array}$ & $\begin{array}{c}-0.060 * * * \\
(-11.32)\end{array}$ & $\begin{array}{c}-0.139 * * * \\
(-23.04)\end{array}$ \\
\hline RE with Mundlak corrections & $\begin{array}{l}-0.007 \\
(-0.87)\end{array}$ & $\begin{array}{l}0.000 \\
(0.02)\end{array}$ & - & - \\
\hline RE with Mundlak corrections & $\begin{array}{l}-0.007 \\
(-0.85)\end{array}$ & $\begin{array}{l}0.000 \\
(0.04)\end{array}$ & $\begin{array}{c}-0.036 * * * \\
(-6.01)\end{array}$ & $\begin{array}{c}-0.045^{* * *} \\
(-4.89)\end{array}$ \\
\hline Sample size & \multicolumn{4}{|c|}{40996} \\
\hline \multicolumn{5}{|l|}{ Impact on job satisfaction } \\
\hline Pooled probit & $\begin{array}{c}-0.065 * * \\
(-2.42)\end{array}$ & $\begin{array}{c}-0.258 * * * \\
(-10.37)\end{array}$ & 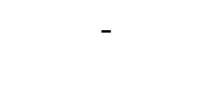 & - \\
\hline Pooled probit & $\begin{array}{l}-0.049 * \\
(-1.71)\end{array}$ & $\begin{array}{c}-0.265 * * * \\
(-9.91)\end{array}$ & $\begin{array}{c}-0.516 * * * \\
(-30.46)\end{array}$ & $\begin{array}{l}-0.024 \\
(-1.16)\end{array}$ \\
\hline RE with Mundlak corrections & $\begin{array}{l}0.010 \\
(0.25)\end{array}$ & $\begin{array}{c}-0.128 * * * \\
(-2.91)\end{array}$ & - & - \\
\hline RE with Mundlak corrections & $\begin{array}{c}0.029 \\
(0.68)\end{array}$ & $\begin{array}{c}-0.120^{* *} \\
(-2.54)\end{array}$ & $\begin{array}{c}-0.423 * * * \\
(-16.05)\end{array}$ & $\begin{array}{c}-0.082 * * \\
(-2.17)\end{array}$ \\
\hline Sample size & \multicolumn{4}{|c|}{41860} \\
\hline
\end{tabular}

Notes: HILDA waves 2001-2008. Estimates refer to coefficients from an earnings equation and coefficients from a probit model for the analysis of job satisfaction. T statistics are reported in parenthesis. *, **, *** denote significance at the $1 \%, 5 \%$ and $10 \%$ level respectively. A full set of variables included but not reported here are presented in Appendix Table 1.

Table 11 shows that the wage penalty associated with a work-limiting disability is 9 per cent, compared to 2 per cent for a non-work-limiting disability, consistent with an unobserved 
productivity effect being evident among the former. These effects are not sensitive to the inclusion of the controls for mismatch, which are themselves negatively associated with wages. This is consistent with there being a separate earnings penalty for being over-skilled and over-educated, presumably as the consequence of mismatched employees being less productive at work than their well-matched counterparts.

Interestingly, the negative relationship between disability and earnings disappears in the RE Mundlak specification, suggesting that the negative cross-sectional association estimated using the OLS method reflects the presence of considerable unobserved individual heterogeneity between those with and those without a disability, and that the panel estimation method produces no evidence of a wage penalty arising from becoming work-limited disabled within the last year. ${ }^{4}$ This is an important result since the existing evidence on the impact of disability on earnings, which typically finds a substantial wage penalty associated with disability, has primarily relied on cross sectional analysis (see, for example, Jones et al., 2006). This result should, however, be interpreted with care, because there will be several institutional factors that would act in a protective way and hinder the emergence of a wage penalty right after the onset of a work-limiting disability. Downward wage movements are very hard to implement and anti-discrimination laws are designed to ameliorate the negative labour market effects of disability. Further, as the data clearly show, many of the reported disability cases are followed by a recovery, in which case we would not expect to see much of a short-run wage change. The present analysis does not investigate the mechanisms through which a disability onset may influence the longer term outcomes of either wages or job satisfaction, and it is those outcomes that may be influenced by the onset of a disability.

\footnotetext{
${ }^{4}$ This is also true in specifications estimated separately for males, females, and full-time and part-time workers.
} 
Unsurprisingly, the influence of disability on job satisfaction is also reduced (with a coefficient which is about 50 per cent less) in the Mundlak specification. However, the influence of work-limiting disability remains negative. There is therefore evidence that becoming work-limited disabled is associated with an immediate and substantial reduction in satisfaction, despite there being no evidence of an immediate wage penalty. ${ }^{5}$

For all workers, mismatch in terms of being over-skilled, but to a lesser extent being overeducated, is an important determinant of job satisfaction. Even after controlling for unobserved individual heterogeneity becoming over-skilled is associated with a significant reduction in job satisfaction, consistent with the view that overskilling is an involuntary state. As with the analysis of earnings, the influence of disability is not sensitive to the introduction of controls for mismatch suggesting they are not a key mechanism through which disability affects earnings or job satisfaction.

The above analysis constrains the influence of mismatch to be common across disability groups, which may not be the case. Results from estimating Equation 5 (for wages, and its binary counterpart for job satisfaction) in Tables 12 and 13 show what happens when this assumption is relaxed by introducing interaction terms between disability and mismatch.

\footnotetext{
${ }^{5}$ This effect is stronger for males than females and for full-time than part-time workers.
} 
Table 12: The impact of disability and over-skilling on earnings and job satisfaction

\begin{tabular}{|c|c|c|c|c|c|}
\hline & \multicolumn{5}{|c|}{ Relative to non-disabled and well-matched } \\
\hline & $\begin{array}{l}\text { Non-work- } \\
\text { limiting } \\
\text { disabled }\end{array}$ & $\begin{array}{l}\text { Work- } \\
\text { limiting } \\
\text { disabled }\end{array}$ & $\begin{array}{l}\text { Over- } \\
\text { skilled }\end{array}$ & $\begin{array}{c}\text { Non-work- limiting } \\
\text { disabled*Over- } \\
\text { skilled }\end{array}$ & $\begin{array}{c}\text { Work-limiting } \\
\text { disabled*Over- } \\
\text { skilled }\end{array}$ \\
\hline \multicolumn{6}{|c|}{ Impact on weekly wage } \\
\hline Pooled OLS & $\begin{array}{r}-0.017 * \\
(-1.77)\end{array}$ & $\begin{array}{c}-0.064 * * * \\
(-6.72)\end{array}$ & $\begin{array}{c}-0.068 * * * \\
(-11.98)\end{array}$ & $\begin{array}{l}0.004 \\
(0.20)\end{array}$ & $\begin{array}{c}-0.069 * * * \\
(-3.56)\end{array}$ \\
\hline RE with Mundlak & -0.004 & 0.005 & $-0.036 * * *$ & -0.013 & -0.022 \\
\hline corrections & $(-0.46)$ & $(0.48)$ & $(-5.69)$ & $(-0.69)$ & $(-1.08)$ \\
\hline Sample size & \multicolumn{5}{|c|}{40996} \\
\hline \multicolumn{6}{|c|}{ Impact on job satisfaction } \\
\hline Pooled probit & $\begin{array}{l}-0.039 \\
(-1.16)\end{array}$ & $\begin{array}{c}-0.308^{* * *} \\
(-9.92)\end{array}$ & $\begin{array}{c}-0.529 * * * \\
(-29.21)\end{array}$ & $\begin{array}{r}-0.032 \\
(0.51)\end{array}$ & $\begin{array}{c}0.159 * * * \\
(-2.68)\end{array}$ \\
\hline RE with Mundlak & 0.031 & $-0.164 * * *$ & $-0.438 * * *$ & -0.006 & $0.162^{*}$ \\
\hline corrections & $(0.63)$ & $(-3.14)$ & $(-15.72)$ & $(-0.08)$ & $(1.85)$ \\
\hline Sample size & \multicolumn{5}{|c|}{41860} \\
\hline
\end{tabular}

Notes: See notes to Table 11.

In the pooled specifications over-skilling has a greater wage penalty amongst the worklimiting disabled. The suggestion from this result is that overskilling is more heavily penalised in the case of people with work-limiting disabilities (a result consistent with Jones and Sloane, 2010). The fact that this result is not supported by the panel estimates for wage penalties interacted with work-limiting disabilities, but appears to be supported for job satisfaction losses interacted with work-limiting disabilities, suggests similar interpretations to the ones we provided earlier for the main estimates of both wages and job satisfaction. Wages appear to be harder to change in the short term, while job satisfaction results show that losses in job satisfaction from overskilling are less intense when they coincide with the onset of a work-limiting disability. There are several possible explanations for this, including that the onset of a work-limiting disability is likely to be responsible for a reduction in workcapacity, which, other things equal, may make overskilling less of a serious problem. Further, for work-limiting disabled workers, underutilisation of skills may form part of the accommodations made by employers post disability onset 
Table 13: The impacts of disability and over-education on earnings and job satisfaction

\begin{tabular}{lccccc} 
& $\begin{array}{c}\text { Non-work- } \\
\text { limited } \\
\text { disabled }\end{array}$ & $\begin{array}{c}\text { Work- } \\
\text { limited } \\
\text { disabled }\end{array}$ & $\begin{array}{c}\text { Relative to non-disabled and well-matched } \\
\text { Over- } \\
\text { educated }\end{array}$ & $\begin{array}{c}\text { Non-work- } \\
\text { limited } \\
\text { disabled*Over- } \\
\text { educated }\end{array}$ & $\begin{array}{c}\text { Work-limited } \\
\text { disabled*Over- } \\
\text { educated }\end{array}$ \\
\hline $\begin{array}{l}\text { Impact on weekly wage } \\
\text { Pooled OLS }\end{array}$ & $-0.027^{* * *}$ & $-0.082^{* * *}$ & $-0.145^{* * *}$ & 0.023 & -0.024 \\
RE with Mundlak corrections & $(-2.97)$ & $(-9.02)$ & $(-23.47)$ & $(1.11)$ & $(-1.23)$ \\
Sample size & -0.009 & 0.001 & $-0.052^{* * *}$ & 0.012 & -0.002 \\
\hline Impact on job satisfaction & $(-1.01)$ & $(0.14)$ & $(-5.67)$ & $(0.63)$ & $(-0.10)$ \\
Pooled probit & & & 45725 & & \\
RE with Mundlak corrections & $-0.088^{* * *}$ & $-0.261^{* * *}$ & $-0.099 * * *$ & $0.110^{*}$ & 0.021 \\
Sample size & $(-2.93)$ & $(-9.25)$ & $(-4.97)$ & $(1.65)$ & $(0.36)$ \\
\hline
\end{tabular}

Notes: See notes to Table 11.

In terms of over-education (Table 13) none of the interaction terms are significant in the earnings equations. There seems to be some evidence that being over-educated is associated with a positive impact on job satisfaction amongst the non-work-limited in the pooled regression, but this effect is not significant in the RE Mundlak specification.

\subsection{Disability and the facets of job satisfaction}

Given the important influence of disability on overall job satisfaction, we consider how this influence varies across the different facets of job satisfaction. Estimation results are presented in Table 14. The facets investigated are pay, job security, work, hours and flexibility.

The pooled estimation results suggest that the presence of non-work-limiting disabilities is associated with lower job satisfaction regarding pay, job security, work, and hours worked, but, interestingly, not flexibility satisfaction. In the RE Mundlak estimations the coefficients on work and hours satisfaction remain significant, though reduced in size, suggesting that the onset of such a disability although not directly limiting work ability, may be making work less pleasant than it was before. This could be in an indirect and less obvious way. There are 
many possible explanations for this including greater difficulty to travel to work, changes in preferences for work and possibly different treatment by employers and co-workers. The presence of a non-work-limiting disability appears to be independent of overskilling or overeducation mismatch.

Results on work-limiting disabilities are more robust. Work-limiting disability has a negative influence across all five facets of job satisfaction and, although often smaller in magnitude in the RE Mundlak specification, disability consistently remains significant. The onset of a disability which is work-limiting in nature is associated with a decline in every aspect of job satisfaction measured here. Indeed, despite the focus on earnings within the literature, the pay satisfaction facet appears to be the least important one. When overskilled and over-educated dummies are included in the estimation in Table 14, the coefficients on disability are little affected. Overskilling has a negative influence on all job satisfaction facets, an influence that remains strong even after individual unobserved heterogeneity has been controlled for, indicating that overskilling makes people less happy at work.

Overeducation has a negative but much weaker satisfaction effect, which is not significant in the cases of job security, hours worked and flexibility of work, strongly suggesting the presence of compensating job attributes for the overeducated workers. 
Table 14: The impact of disability on facets of job satisfaction

\begin{tabular}{|c|c|c|c|c|}
\hline & \multicolumn{4}{|c|}{ Relative to non-disabled and well-matched } \\
\hline & $\begin{array}{c}\text { Non-work- limited } \\
\text { disabled }\end{array}$ & $\begin{array}{l}\text { Work-limited } \\
\text { disabled }\end{array}$ & Over-skilled & $\begin{array}{c}\text { Over- } \\
\text { educated }\end{array}$ \\
\hline \multicolumn{5}{|l|}{ Pay satisfaction } \\
\hline Pooled probit & $\begin{array}{c}-0.061 * * \\
(-2.51)\end{array}$ & $\begin{array}{c}-0.185 * * * \\
(-7.96)\end{array}$ & - & - \\
\hline Pooled probit & $\begin{array}{c}-0.066 * * * \\
(-2.59)\end{array}$ & $\begin{array}{c}-0.182 * * * \\
(-7.36)\end{array}$ & $\begin{array}{c}-0.221 * * * \\
(-13.97)\end{array}$ & $\begin{array}{c}-0.123 * * * \\
(-6.75)\end{array}$ \\
\hline RE with Mundlak corrections & $\begin{array}{l}0.013 \\
(0.37)\end{array}$ & $\begin{array}{c}-0.100 * * \\
(-2.44)\end{array}$ & - & - \\
\hline RE with Mundlak corrections & $\begin{array}{l}0.014 \\
(0.36)\end{array}$ & $\begin{array}{c}-0.087 * * \\
(-1.98)\end{array}$ & $\begin{array}{c}-0.112 * * * \\
(-4.57)\end{array}$ & $\begin{array}{c}-0.088 * * * \\
(-2.59)\end{array}$ \\
\hline $\mathrm{N}$ & \multicolumn{4}{|c|}{41852} \\
\hline \multicolumn{5}{|l|}{ Job security satisfaction } \\
\hline Pooled probit & $\begin{array}{c}-0.061 * * \\
(-2.19)\end{array}$ & $\begin{array}{c}-0.274 * * * \\
(-10.90)\end{array}$ & - & - \\
\hline Pooled probit & $\begin{array}{c}-0.055 * * \\
(-1.89)\end{array}$ & $\begin{array}{c}-0.270 * * * \\
(-10.07)\end{array}$ & $\begin{array}{c}-0.209 * * * \\
(-11.79)\end{array}$ & $\begin{array}{l}-0.023 \\
(-1.12)\end{array}$ \\
\hline RE with Mundlak corrections & $\begin{array}{l}0.044 \\
(1.03)\end{array}$ & $\begin{array}{c}-0.125 * * * \\
(-2.71)\end{array}$ & - & - \\
\hline RE with Mundlak corrections & $\begin{array}{l}0.053 \\
(1.18)\end{array}$ & $\begin{array}{c}-0.115^{* *} \\
(-2.31)\end{array}$ & $\begin{array}{c}-0.131 * * * \\
(-4.61)\end{array}$ & $\begin{array}{l}-0.006 \\
(-0.14)\end{array}$ \\
\hline Sample size & \multicolumn{4}{|c|}{41851} \\
\hline Work satisfaction & & & & \\
\hline Pooled probit & $\begin{array}{c}-0.082 * * * \\
(-3.14)\end{array}$ & $\begin{array}{c}-0.198 * * * \\
(-8.02)\end{array}$ & - & - \\
\hline Pooled probit & $\begin{array}{c}-0.086 * * * \\
(-3.12)\end{array}$ & $\begin{array}{c}-0.209 * * * \\
(-7.88)\end{array}$ & $\begin{array}{c}-0.637 * * * \\
(-38.92)\end{array}$ & $\begin{array}{c}-0.092 * * * \\
(-4.63)\end{array}$ \\
\hline RE with Mundlak corrections & $\begin{array}{l}-0.073^{*} \\
(-1.86)\end{array}$ & $\begin{array}{c}-0.161 * * * \\
(-3.69)\end{array}$ & - & - \\
\hline RE with Mundlak corrections & $\begin{array}{l}-0.076^{*} \\
(-1.82)\end{array}$ & $\begin{array}{c}-0.174 * * * \\
(-3.68)\end{array}$ & $\begin{array}{c}-0.512 * * * \\
(-20.08)\end{array}$ & $\begin{array}{c}-0.144 * * * \\
(-3.88)\end{array}$ \\
\hline Sample size & \multicolumn{4}{|c|}{41863} \\
\hline \multicolumn{5}{|l|}{ Hours satisfaction } \\
\hline Pooled probit & $\begin{array}{c}-0.090 * * * \\
(-3.68)\end{array}$ & $\begin{array}{c}-0.242 * * * \\
(-10.27)\end{array}$ & - & - \\
\hline Pooled probit & $\begin{array}{c}-0.079 * * * \\
(-3.04)\end{array}$ & $\begin{array}{c}-0.248 * * \\
(-9.87)\end{array}$ & $\begin{array}{c}-0.254^{* * *} \\
(-15.75)\end{array}$ & $\begin{array}{l}0.004 \\
(0.22)\end{array}$ \\
\hline RE with Mundlak corrections & $\begin{array}{l}-0.065^{*} \\
(-1.82)\end{array}$ & $\begin{array}{c}-0.167 * * * \\
(-4.12)\end{array}$ & - & - \\
\hline RE with Mundlak corrections & $\begin{array}{l}-0.052 \\
(-1.36)\end{array}$ & $\begin{array}{c}-0.157 * * * \\
(-3.60)\end{array}$ & $\begin{array}{c}-0.179 * * * \\
(-7.28)\end{array}$ & $\begin{array}{l}-0.050 \\
(-1.45)\end{array}$ \\
\hline Sample size & \multicolumn{4}{|c|}{41861} \\
\hline \multicolumn{5}{|l|}{ Flexibility satisfaction } \\
\hline Pooled probit & $\begin{array}{l}-0.009 \\
(-0.34)\end{array}$ & $\begin{array}{c}-0.177 * * * \\
(-7.33)\end{array}$ & - & - \\
\hline Pooled probit & $\begin{array}{l}0.006 \\
(0.22)\end{array}$ & $\begin{array}{c}-0.184 * * * \\
(-7.16)\end{array}$ & $\begin{array}{c}-0.206^{* * *} \\
(-12.44)\end{array}$ & $\begin{array}{l}-0.001 \\
(-0.07)\end{array}$ \\
\hline RE with Mundlak corrections & $\begin{array}{l}0.021 \\
(0.57)\end{array}$ & $\begin{array}{c}-0.218^{* * *} \\
(5.13)\end{array}$ & - & - \\
\hline RE with Mundlak corrections & $\begin{array}{l}0.030 \\
(0.77)\end{array}$ & $\begin{array}{c}-0.232 * * * \\
(-5.08)\end{array}$ & $\begin{array}{c}-0.106^{* * *} \\
(-4.11)\end{array}$ & $\begin{array}{l}-0.006 \\
(-0.17)\end{array}$ \\
\hline Sample size & & & & \\
\hline
\end{tabular}

Note: HILDA waves 1 to 8 . Sample sizes in person-years. 
In Tables 15 and 16, we introduce interaction terms between disability and job mismatch.

There is very little to report by way of statistical significance of the interaction coefficients, with only two exceptions.

Table 15: The impact of disability and over-skilling on facets of job satisfaction

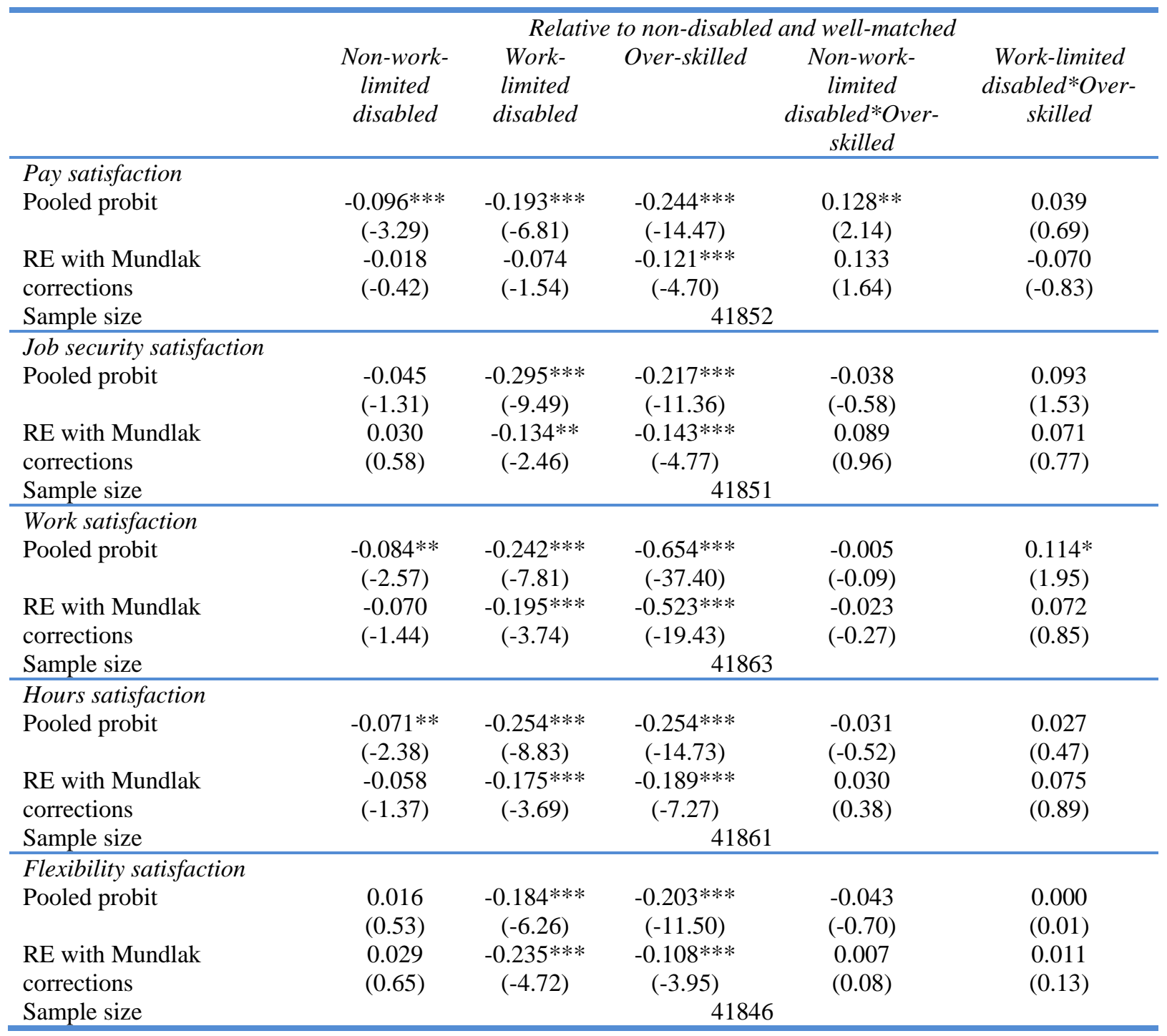

Note: HILDA waves 1 to 8. Sample sizes in person-years.

First, the overskilled workers with a work-limiting disability appear to have a lesser reduction in their work satisfaction in the pooled estimation, but not in the panel RE Mundlak estimation. Second, the overeducated with a work-limiting disability are significantly less satisfied with their hours of work, suggesting that any hours compensating advantage they 
may have enjoyed prior to the onset of their disability does not adapt sufficiently to accommodate the changed circumstances that a work-limiting disability brings.

Table 16: The impact of disability and over-education on facets of job satisfaction

\begin{tabular}{|c|c|c|c|c|c|}
\hline & \multicolumn{5}{|c|}{ Relative to non-disabled and well-matched } \\
\hline & $\begin{array}{l}\text { Non-work- } \\
\text { limited } \\
\text { disabled }\end{array}$ & $\begin{array}{l}\text { Work- } \\
\text { limited } \\
\text { disabled }\end{array}$ & $\begin{array}{c}\text { Over- } \\
\text { educated }\end{array}$ & $\begin{array}{c}\text { Non-work- } \\
\text { limited } \\
\text { disabled*Over- } \\
\text { educated }\end{array}$ & $\begin{array}{c}\text { Work-limited } \\
\text { disabled*Over- } \\
\text { educated }\end{array}$ \\
\hline \multicolumn{6}{|l|}{ Pay satisfaction } \\
\hline Pooled probit & $\begin{array}{c}-0.092^{* * * *} \\
(-3.39)\end{array}$ & $\begin{array}{c}-0.170^{* * *} \\
(-6.45)\end{array}$ & $\begin{array}{c}-0.145 * * * \\
(-8.01)\end{array}$ & $\begin{array}{c}0.152^{* *} \\
(2.51)\end{array}$ & $\begin{array}{l}-0.056 \\
(-1.02)\end{array}$ \\
\hline RE with Mundlak & 0.008 & -0.070 & $-0.073 * *$ & 0.027 & -0.130 \\
\hline corrections & $(0.20)$ & $(-1.56)$ & $(-2.22)$ & $(0.33)$ & $(-1.52)$ \\
\hline Sample size & \multicolumn{5}{|c|}{46873} \\
\hline \multicolumn{6}{|l|}{ Job security satisfaction } \\
\hline Pooled probit & $\begin{array}{c}-0.055^{*} \\
(-1.79)\end{array}$ & $\begin{array}{c}-0.265^{* * *} \\
(-9.29)\end{array}$ & $\begin{array}{c}-0.046 * * \\
(-2.21)\end{array}$ & $\begin{array}{l}-0.025 \\
(-0.37)\end{array}$ & $\begin{array}{l}-0.034 \\
(-0.57)\end{array}$ \\
\hline RE with Mundlak & $0.079 *$ & -0.103 & 0.002 & $-0.164 *$ & -0.091 \\
\hline corrections & $(1.69)$ & $(-2.02)$ & $(0.04)$ & $(-1.71)$ & $(-0.97)$ \\
\hline Sample size & \multicolumn{5}{|c|}{46874} \\
\hline \multicolumn{6}{|l|}{ Work satisfaction } \\
\hline Pooled probit & $\begin{array}{c}-0.093 * * * \\
(-3.18)\end{array}$ & $\begin{array}{c}-0.191 * * * \\
(-6.79)\end{array}$ & $\begin{array}{c}-0.181 * * * \\
(-9.37)\end{array}$ & $\begin{array}{l}0.052 \\
(0.81)\end{array}$ & $\begin{array}{l}-0.015 \\
(-0.27)\end{array}$ \\
\hline RE with Mundlak & $-0.093 * *$ & $-0.152 * * *$ & $0.208 * * *$ & 0.101 & -0.030 \\
\hline corrections & $(-2.14)$ & $(-3.15)$ & $(-5.86)$ & (1.13) & $(-0.33)$ \\
\hline Sample size & \multicolumn{5}{|c|}{46897} \\
\hline \multicolumn{6}{|l|}{ Hours satisfaction } \\
\hline Pooled probit & $\begin{array}{c}-0.112 * * * \\
(-4.09)\end{array}$ & $\begin{array}{c}-0.208 * * * \\
(-7.77)\end{array}$ & $\begin{array}{l}-0.028 \\
(-1.50)\end{array}$ & $\begin{array}{c}0.109 * \\
(1.77)\end{array}$ & $\begin{array}{c}-0.150 * * * \\
(-2.69)\end{array}$ \\
\hline RE with Mundlak & $-0.074^{*}$ & $-0.124 * * *$ & $-0.062 *$ & 0.049 & $-0.192 * *$ \\
\hline corrections & $(-1.87)$ & $(-2.76)$ & $(-1.86)$ & $(0.57)$ & $(-2.25)$ \\
\hline Sample size & \multicolumn{5}{|c|}{46893} \\
\hline \multicolumn{6}{|l|}{ Flexibility satisfaction } \\
\hline Pooled probit & $\begin{array}{l}-0.014 \\
(-0.51)\end{array}$ & $\begin{array}{c}-0.166^{* * * *} \\
(-6.10)\end{array}$ & $\begin{array}{c}-0.031 * \\
(-1.65)\end{array}$ & $\begin{array}{l}0.028 \\
(0.45)\end{array}$ & $\begin{array}{l}-0.047 \\
(-0.81)\end{array}$ \\
\hline RE with Mundlak & 0.037 & $-0.221 * * *$ & -0.024 & -0.081 & 0.014 \\
\hline corrections & $(0.90)$ & $(-4.73)$ & $(-0.67)$ & $(-0.91)$ & $(0.16)$ \\
\hline Sample size & \multicolumn{5}{|c|}{46875} \\
\hline
\end{tabular}

Note: HILDA waves 1 to 8. Sample sizes in person-years.

\section{Conclusion}

This paper is the first to examine the relationship between disability, job mismatch, earnings and job satisfaction in Australia. It thus contributes to the growing analysis of disability and labour market outcomes in Australia which has, until this point, largely focused on issues relating to labour market participation (Oguzoglu, 2010, 2011). Importantly, the nature of the 
HILDA survey facilitates the application of panel data techniques which control for the influence of unobserved individual heterogeneity. Hence, this paper makes an important contribution to the existing international literature, where, due to data restrictions, the influence of disability has largely been considered in cross-sectional analyses (Jones et al., 2006, Jones and Sloane, 2010).

In relation to our first research question, namely what is the effect of disability on job mismatch, in contrast to Jones and Sloane (2010) we find no evidence of a relationship between work-limiting disability and over-skilling, though we do so for non-work-limiting disability. We do, however, find evidence of a positive relationship between work-limiting disability and over-education which is consistent with disability onset being associated with relative downward occupational movements.

In terms of the second question, namely what is the effect of disability on wages and whether this effect may be influenced by job mismatch, we find, consistent with the international literature (see, for example, Jones et al. 2006), evidence of a negative association between disability and earnings which is stronger among employees with a work-limiting disability than among employees with a non-work-limiting disability. Importantly, this relationship is not evident once we control for unobserved individual heterogeneity, suggesting it does not represent a short term causal relationship but reflects unobservable differences between those employees that become disabled and those who do not, and the way these differences eventually influence the long run labour market outcomes of people with and without disabilities. This last conclusion is important in the context of the literature and points towards the need for future examination which will distinguish explicitly between the short and long run labour market impacts of the different types of disability. 
In terms of the third question, namely what is the effect of disability on job satisfaction and whether this effect can be influenced by job mismatch, in a similar manner to Uppal (2005) and Schur et al. (2009) who use data from Canada and the US respectively, we find a negative relationship between work-limiting disability and job satisfaction, in the pooled estimation. Further, we find that this relationship is robust to the introduction of methods that control for unobserved individual heterogeneity, and is evident across all facets of job satisfaction. There is thus a comprehensive or multifaceted impact of disability onset on job satisfaction which, undoubtedly, given the relationship between job satisfaction and quit behaviour, enhances the incentive for non-participation among this group. Understanding the reasons for this reduction in job satisfaction is thus of critical policy concern and clearly warrants further investigation.

Consistent with Mavromaras et al. (2010b) we find that mismatch is an important determinant of wages and job satisfaction, and that over-skilling is particularly important for job satisfaction. However, we find no evidence that accounting for mismatch substantially influences the relationship between disability, earnings, and job satisfaction. Further, we find that the influence of disability on the relationship between mismatch, job satisfaction and earnings is relatively modest. The main exception is that over-skilling is associated with a smaller (negative) impact on job satisfaction amongst work-limiting disabled employees suggesting that for this group mismatch may be less unwelcome than for non-disabled employees. 


\section{References}

Allen, J. and Van der Velden, R., 2001. Educational Mismatch Versus Skill Mismatches: Effects on Wage, Job Satisfaction and On-the-Job Search. Oxford Economic Papers, 53, 43452.

Australian Bureau of Statistics, 2003, Survey of Disability, Ageing and Carers, Canberra.

Battu, H., Belfield, C. and Sloane, P., 1999. Overeducation Among Graduates: A Cohort View. Education Economics, 7, 21-38.

Blazquez, M. and Malo, M., 2005. Educational Mismatch and Labour Mobility of People with Disabilities: The Spanish Case. Revista de Economia Labora, 2, 31-55.

Cai, L., Mavromaras, K. and Oguzoglu, U. 2008. The Effects of Health and Health Shocks on Hours Worked, IZA Discussion Paper No. 3496.

Chevalier, A., 2003. Measuring Overeducation. Economica, 70, 509-31.

Commonwealth of Australia, 2008. National Mental Health and Disability Employment Strategy Update: Setting the Direction. Australian Government, Canberra.

DeLeire, T., 2001. Changes in Wage Discrimination against People with Disabilities: 198493. Journal of Human Resources, 36, 114-58.

Dustmann, C. and Rochina-Barrachina, M., 2007. Selection Correction in Panel Data Models: An Application to the Estimation of Females' Wage Equations. Econometrics Journal, 10 (2), 263-293.

European Commission, 2009. New Skills for New Jobs; Anticipating and Matching Labour Market and Skill Needs. Luxembourg.

Fleming, C. and Kler, P., 2008. I'm Too Clever for This Job: A Bivariate Probit Analysis on Overeducation and Job Satisfaction in Australia. Applied Economics, 40, 1123-38.

Green, F. and McIntosh, S., 2007. Is There a Genuine Underutilisation of Skills Amongst the Overqualified? Applied Economics, 39, 427-39.

Jones, M., Latreille, P. and Sloane, P., 2006. Disability, Gender and the British Labour Market. Oxford Economic Papers, 58, 407-49.

Jones, M. and Sloane, P., 2010. Disability and Skill Mismatch, Economic Record, 86, 101-14.

Kler, P., 2005. Graduate Overeducation in Australia: A Comparison of the Mean and Objective Methods, Education Economics, 13, 47-72.

Mavromaras, K., Oguzoglu, U., Black, D. and Wilkins, R., 2006. Disability and Employment in the Australian Labour Market. Report prepared for the Commonwealth Department of Employment and Workplace Relations, Canberra. 
Mavromaras, K., McGuinness, S., O’Leary, N., Sloane, P. and Fok, K., 2010a. The Problem of Overskilling in Australia and Britain. Manchester School, 78, 219-41.

Mavromaras, K., McGuinness, S., O’Leary, N., Sloane, P. and Wei, Z., 2010b. Job Mismatches and Labour Market Outcomes: Panel Evidence on Australian University Graduates. NILS Working Paper no. 163.

McGuinness, S. and Wooden, M., 2009. Overskilling, Job Insecurity and Career Mobility, Industrial Relations, 48, 265-86.

Mundlak, Y., 1978. On the Pooling of Time Series and Cross Section Data, Econometrica, 46, 69-85.

Oguzoglu, U. (2010) Disability and Multi-State Labour Force Choices with State Dependence, IZA Discussion Paper No. 5408.

Oguzoglu, U. (2011) Severity of Work Disability and Work, forthcoming Economic Record.

Schur, L., Kruse, D., Blasi, J and Blanck, P. (2009) Is disability disabling in all workplaces? Workplace disparities and corporate culture, Industrial Relations, 48, 381-410.

Sloane, P., 2003. Much Ado about Nothing? What does the Over-education Literature Really Tell us? In Over-education in Europe; Current Issues in Theory and Policy, Editors Buchel F., deGrip A. And Mertens A.,Edward Elgar, Cheltenham.

Sloane, P., Battu, H. and Seaman, P., 1999. Overeducation, Undereducation and the British Labour Market. Applied Economics, 31, 1437-54.

Uppal, S., 2005. Disability, Workplace Characteristics and Job Satisfaction, International Journal of Manpower, 26, 336-49.

Wilkins, R., 2004. The Effects of Disability on Labour Force Status in Australia. Australian Economic Review, 37, 359-83.

Watson, N. and Wooden, M., 2004. The HILDA Survey Four Years On. Australian Economic Review, 37, 343-349. 


\section{Appendix I}

\section{Definition of Variables:}

\section{Disability variables:}

Non-work-limiting disability: Dummy variable, takes the value 1 if an individual has a nonwork-limiting disability, zero otherwise.

Work-limiting disability: Dummy variable, takes the value 1 if an individual has a worklimiting disability, zero otherwise.

No disability is the reference category.

Overskilled: Dummy variable, takes the value 1 if is overskilled, zero otherwise.

Overeducated: Dummy variable, takes the value 1 if is overeducated, zero otherwise.

Wage: Log of current weekly gross wages and salary from the main job.

Overall job satisfaction: Dummy variable, takes the value 1 if overall job satisfaction is 7 or above, zero if 0 to 6 .

Facets of job satisfaction: Pay satisfaction, job security satisfaction, work satisfaction, hours satisfaction and flexibility satisfaction are defined in the same way as overall job satisfaction.

Female: Dummy variable, takes the value 1 if is female, zero otherwise.

Age:

Age between 25 and 39: Dummy variable, takes the value 1 if age is between 25 and 39, zero otherwise.

Age between 40 and 54: Dummy variable, takes the value 1 if age is between 40 and 54, zero otherwise.

Age above 54: Dummy variable, takes the value 1 if age is above 54, zero otherwise.

Age below 24 is the reference category.

Married: Dummy variable, takes the value 1 if an individual is married (or de facto), zero otherwise.

Urban: Dummy variable, takes the value 1 if an individual domiciled within a major city, zero otherwise.

Father was a professional: Dummy variable, takes the value 1 if father belonged to a professional occupation, zero otherwise. 


\section{Country of birth:}

Migrant (English speaking country): Dummy variable, takes the value 1 if migrant from an English speaking country, zero otherwise.

Migrant (non-English speaking country): Dummy variable, takes the value 1 if migrant from a non English speaking country, zero otherwise.

Australian born is the reference category.

Hours per week usually worked in main job: Continuous variable, expressed in hours.

Tenure in the current occupation: Continuous variable, expressed in years.

Tenure with current employer: Continuous variable, expressed in years.

\section{Firm size:}

Less than 5 employees: Dummy variable, takes the value 1 if working in a firm which has less than 5 employees, zero otherwise.

5 to 9 employees: Dummy variable, takes the value 1 if working in a firm which has 5 to 9 employees, zero otherwise.

10 to 19 employees. Dummy variable, takes the value 1 if working in a firm which has 10 to 19 employees, zero otherwise.

20 to 49 employees. Dummy variable, takes the value 1 if working in a firm which has 20 to 49 employees, zero otherwise.

More than 49 employees is the reference category.

Children aged between 5 and 14: Dummy variable, takes the value 1 if an individual has children between the ages of 5 and 14 , zero otherwise.

Children aged under 5: Dummy variable, takes the value 1 if an individual has children aged under 5, zero otherwise.

Percent time spent unemployed in last financial year: Continuous variable, value of which lies between 0 and 100 .

Union member: Dummy variable, takes the value 1 if an individual is a member of a trade union, zero otherwise.

\section{Education:}

Only completed school: Dummy variable, takes the value 1 if an individual only completed school, zero otherwise. 
Certificate III/IV . Dummy variable, takes the value 1 if an individual has a certificate III/IV, zero otherwise.

Advanced diploma or diploma: Dummy variable, takes the value 1 if an individual has an advanced diploma or diploma, zero otherwise.

University degree: Dummy variable, takes the value 1 if an individual has a university degree or diploma, zero otherwise.

Did not complete school is the reference category.

\section{Sector:}

Agriculture, forestry and fishing. Dummy variable, takes the value 1 if working in the industry of agriculture, forestry and fishing, zero otherwise.

Mining: Dummy variable, takes the value 1 if working in the industry of mining, zero otherwise.

Electricity, gas, water and waste services: Dummy variable, takes the value 1 if working in the industry of electricity, gas, water and waste services, zero otherwise.

Construction: Dummy variable, takes the value 1 if working in the industry of construction, zero otherwise.

Wholesale trade: Dummy variable, takes the value 1 if working in the industry of wholesale trade, zero otherwise.

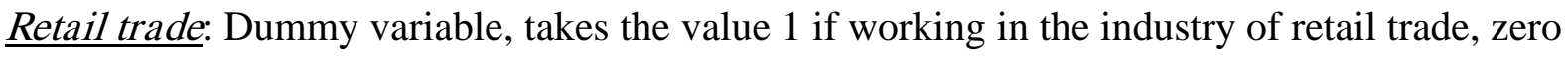
otherwise.

Accommodation and food services: Dummy variable, takes the value 1 if working in the industry of accommodation and food services, zero otherwise.

Transport, postal and warehousing. Dummy variable, takes the value 1 if working in the industry of transport, postal and warehousing, zero otherwise.

Information media and telecommunications: Dummy variable, takes the value 1 if working in the industry of information media and telecommunications, zero otherwise.

Financial and insurance services: Dummy variable, takes the value 1 if working in the industry of financial and insurance services, zero otherwise.

Rental, hiring and real estate services: Dummy variable, takes the value 1 if working in the industry of rental, hiring and real estate services, zero otherwise.

Professional, scientific and technical services: Dummy variable, takes the value 1 if working in the industry of professional, scientific and technical services, zero otherwise.

Administrative and support services: Dummy variable, takes the value 1 if working in the industry of administrative and support services, zero otherwise.

Public administration and safety. Dummy variable, takes the value 1 if working in the industry of public administration and safety, zero otherwise. 
Education and training: Dummy variable, takes the value 1 if working in the industry of education and training, zero otherwise.

Health care and social assistance: Dummy variable, takes the value 1 if working in the industry of health care and social assistance, zero otherwise.

Arts and recreation services: Dummy variable, takes the value 1 if working in the industry of arts and recreation services, zero otherwise.

Other services: Dummy variable, takes the value 1 if working in the industry of other services, zero otherwise.

Manufacturing is the reference category. 
Table A1: Descriptive statistics

\begin{tabular}{|c|c|c|}
\hline Explanatory variable & Mean & $\begin{array}{l}\text { Standard } \\
\text { deviation }\end{array}$ \\
\hline Female & 0.494 & 0.50 \\
\hline Age between 25 and 39 & 0.356 & 0.48 \\
\hline Age between 40 and 54 & 0.350 & 0.48 \\
\hline Age above 54 & 0.078 & 0.27 \\
\hline Married & 0.626 & 0.48 \\
\hline Urban & 0.882 & 0.32 \\
\hline Father was a professional & 0.165 & 0.37 \\
\hline Migrant (English speaking country) & 0.091 & 0.29 \\
\hline Migrant (non-English speaking country) & 0.103 & 0.30 \\
\hline Hours per week usually worked in main job & 35.879 & 14.47 \\
\hline Tenure in the current occupation & 7.957 & 9.00 \\
\hline Tenure with current employer & 5.761 & 7.23 \\
\hline Firm has less than 5 employees & 0.095 & 0.29 \\
\hline Firm has 5 to 9 employees & 0.125 & 0.33 \\
\hline Firm has 10 to 19 employees & 0.148 & 0.35 \\
\hline Firm has 20 to 49 employees & 0.183 & 0.39 \\
\hline Have children aged between 5 and 14 & 0.243 & 0.43 \\
\hline Have children aged under 5 & 0.117 & 0.32 \\
\hline $\begin{array}{l}\text { Percent time spent unemployed in last } \\
\text { financial year }\end{array}$ & 2.538 & 11.65 \\
\hline Union member & 0.283 & 0.45 \\
\hline Completed school & 0.194 & 0.40 \\
\hline Certificate III/IV & 0.204 & 0.40 \\
\hline Advanced diploma or diploma & 0.090 & 0.29 \\
\hline University degrees & 0.261 & 0.44 \\
\hline Agriculture, forestry and fishing & 0.021 & 0.14 \\
\hline Mining & 0.017 & 0.13 \\
\hline Electricity, gas, water and waste services & 0.011 & 0.10 \\
\hline Construction & 0.053 & 0.22 \\
\hline Wholesale trade & 0.034 & 0.18 \\
\hline Retail trade & 0.109 & 0.31 \\
\hline Accommodation and food services & 0.068 & 0.25 \\
\hline Transport, postal and warehousing & 0.043 & 0.20 \\
\hline Information media and telecommunications & 0.027 & 0.16 \\
\hline Financial and insurance services & 0.038 & 0.19 \\
\hline Rental, hiring and real estate services & 0.013 & 0.11 \\
\hline Professional, scientific and technical services & 0.064 & 0.25 \\
\hline Administrative and support services & 0.024 & 0.15 \\
\hline Public administration and safety & 0.079 & 0.27 \\
\hline Education and training & 0.110 & 0.31 \\
\hline
\end{tabular}


Health care and social assistance

0.130

0.34

Arts and recreation services

0.018

0.13

Other services

0.033

0.18

Note:The sample consists of all working age employees from HILDA 2001-2008, and includes 52208 personwave observations. 